\title{
CERITA RAKYAT SUNAN MURIA: PENDEKATAN STRUKTURAL DAN NILAI KARAKTER
}

\author{
Hidar Amaruddin ${ }^{1}$, Yanuar Bayu Isnaeni ${ }^{2}$. Herman J. Waluyo ${ }^{3}$, Sahid Teguh Widodo ${ }^{4}$ \\ ${ }^{1}$ Universitas Negeri Semarang, Indonesia \\ 2,3,4 Universitas Sebelas Maret, Indonesia \\ E-mail: hidars46@gmail.com
}

\begin{abstract}
This article aims to describe the structure contained in Sunan Muria Folk Literature and describe the character values in Sunan Muria Folk Literature. This research is a qualitative descriptive study. The type of plot used in Sunan Muria Folk Literature in Kudus Regency is a straight or advanced plot. The dominant figure in the Sunan Muria Folk Literature in Kudus Regency is a good human character. More background is used in this folk literature. Sunan Muria Folk Literature in Kudus Regency contains varied suggestions. The character values in this folk literature include religious values, honesty, tolerance, discipline, hard work, independence, democratization, friendship/ communicative, peace, social life, and the value of responsibility.
\end{abstract}

Keywords: folk literature; structural; character values.

Abstrak: Artikel ini bertujuan untuk mendeskripsikan struktur yang terkandung dalam Sastra Rakyat Sunan Muria dan menguraikan nilai-nilai karakter dalam Sastra Rakyat Sunan Muria. Penelitian ini adalah penelitian deskriptif kualitatif. Jenis plot yang digunakan dalam Sastra Rakyat Sunan Muria di Kabupaten Kudus adalah plot lurus atau maju. Tokoh dominan dalam Sastra Rakyat Sunan Muria di Kabupaten Kudus adalah karakter manusia yang baik. Latar belakang tempat lebih banyak digunakan dalam literatur rakyat ini. Sastra Rakyat Sunan Muria di Kabupaten Kudus berisi saran variatif. Nilai-nilai karakter yang dalam literatur rakyat ini antara lain nilai religi, kejujuran, toleransi, disiplin, kerja keras, kemandirian, demokratisasi, persahabatan/komunikatif, damai, kehidupan sosial, dan nilai tanggung jawab.

Kata Kunci: cerita rakyat; struktural; nilai karakter

Permalink/DOI: http://dx.doi.org/10.15408/dialektika.v6i2.13561 


\section{Pendahuluan}

Cerita rakyat merupakan bagian budaya yang berkembang di masyarakat sejak dahulu. Keberadaan cerita rakyat menggambarkan kisah seseorang atau kondisi masyarakat pada masa lampau. Seperti yang dijelaskan oleh Gusnetti bahwa cerita rakyat menjadi khazanah kekayaan sejarah budaya yang ada di Indonesia. Secara umum, cerita rakyat mengisahkan peristiwa atau kejadian di suatu tempat, atau asal-usul dari suatu tempat. ${ }^{1}$ Tokoh yang muncul dalam cerita rakyat diwujudkan dalam bentuk manusia, binatang, bahkan dewa. Cerita rakyat juga bermakna sebagai hiburan, juga mampu dijadikan pengantar pesan moral yang dikenal secara umum sebagai“suri tauladan”.

Ananda menjelaskan sastra daerah adalah salah satu dari bagian tradisi lisan atau bisa disebut sastra lisan. Sastra lisan mencakup prosa dan puisi lisan yang dalam penyampaiannya menggunakan bahasa daerah (lisan). ${ }^{2}$ Tiap daerah yang ada di Indonesia memiliki sastra lisan yang khas, setiap etnik kelompok pun mempunyai tradisi yang mengandung berbagai pemikiran yang mencerminkan makna falsafah berakar dari kearifan lokal setempat.

Cerita rakyat di Kabupaten Kudus merupakan cerita rakyat yang tumbuh dan berkembang secara lisan dan menyebar turun-temurun dari generasi ke generasi berikutnya. Pewarisan tersebut menunjukkan bahwa masyarakat Kudus sangat arif dalam melestarikan cerita rakyat di daerahnya. Apresiasi masyarakat terlihat pada kegiatan-kegiatan tradisi di desanya masing-masing. Selain itu, cerita-cerita rakyat di desa seringkali dijadikan tema dalam kegiatan karnaval budaya yang diselenggarakan setiap tahun oleh Dinas Pariwisata dan Kebudayaan setempat. Pelestarian dalam kegiatan tersebut belumlah cukup manakala belum banyak yang mendokumentasikan cerita rakyat di Kabupaten Kudus dalam bentuk buku.

Berdasarkan survei di lapangan, salah cerita rakyat di Kabupaten Kudus yang belum terdokumentasi dengan baik adalah cerita rakyat Sunan Muria. Penulis belum menemukan buku cerita rakyat Sunan Muria di desa-desa yang memiliki cerita rakyat yang berkaitan erat dengan Sunan Muria. Kurangnya referensi buku cerita rakyat Sunan Muria juga dipengaruhi oleh terbatasnya peneliti cerita rakyat tentang Sunan Muria. Selain itu, berdasarkan fakta di lapangan menunjukkan bahwa jumlah narasumber cerita rakyat di Kudus sangat

${ }^{1}$ Syofiani Gusnetti dan Romi Isnanda, "Struktur dan Nilai-nilai Pendidikan dalam Cerita Rakyat Kabupaten Tanah Datar Provinsi Sumatera Barat,” Jurnal Gramatika. Vol. 1, No. 2.

${ }^{2}$ Refisa Ananda, “Kajian Fungsi Sastra Lisan Kaba Urang Tanjuang Karang pada Pertunjukan Dendang Pauah,” STKIP Siliwangi Journals, Vol.4, No.2. 
sedikit karena yang bersangkutan sudah meninggal dan tidak mewariskan cerita rakyat itu kepada keturunannya. Keterbatasan narasumber dan referensi cerita rakyat Sunan Muria sangat disayangkan, mengingat pentingnya masyarakat untuk meneladani Sunan Muria yang notabenenya salah satu tokoh besar agama di Kabupaten Kudus. Cerita rakyat Sunan Muria di Kabupaten Kudus memiliki nilai-nilai edukasi yang dapat dijadikan teladan bagi anak, utamanya dalam lingkup keluarga maupun sekolah.

Pentingnya nilai-nilai edukasi dalam cerita rakyat Sunan Muria dapat digunakan sebagai salah satu usaha menanamkan pendidikan karakter siswa di sekolah. Hal ini relevan dengan pelaksanaan kurikulum bahasa Jawa di SMA yang di dalamnya terdapat materi cerita rakyat. Dalam materi cerita rakyat tersebut, siswa diarahkan untuk mencari dan mengapresiasi cerita rakyat yang diperolehnya. Secara tidak langsung cerita rakyat yang diperoleh memberikan pembelajaran kepada siswa untuk meneladani tokoh-tokoh dalam cerita rakyat tersebut. Ini menunjukkan bahwa cerita rakyat memiliki peranan penting dalam penanaman pendidikan karakter. Sebagaimana yang diungkapkan Muslich, pendidikan karakter bertujuan meningkatkan mutu penyelenggaraan dan hasil pendidikan yang mangarah pada pencapaian pembentukan karakter dan akhlak mulia peserta didik secara utuh, terpadu, dan seimbang. ${ }^{3}$ Pentingnya nilai pendidikan karakter dalam Cerita Rakyat Sunan Muria di Kabupaten Kudus mendorong penulis untuk meneliti cerita rakyat ini sebagai bentuk usaha pelestarian cerita rakyat.

Usaha untuk melestarikan cerita rakyat dilakukan oleh Mieder dalam penelitiannya menerangkan penelitian folklornya berkaitan dengan mantra dan kutukan yang dirumuskan menjadi pepatah, termasuk binatang yang berbicara, berekspresi seperti mengindikasikan emosi. Folklor yang diteliti mengenai tokoh binatang yang dapat berbicara seperti manusia. ${ }^{4}$

Penelitian lain dari Gunnell meneliti cerita rakyat yang berasal dari Eropa Utara meliputi: Norske Folkeeventyr, Cerita Populer dari Norse, dan Íslenzkar pjóðsögur og æfintýri. Cerita rakyat tersebut tidak hanya membedakan fungsi dari masing-masing cerita rakyat tersebut, namun juga mengungkapkan hubungan pendidikan di dalamnya.' Gencarella membahas kekosongan ilmiah

${ }^{3}$ Masnur Muslich, Pendidikan Karakter: Menjawab Tantangan Krisis Multidimensional, (Jakarta: Bumi Aksara, 2011).

${ }^{4}$ Wolfgang Mieder, “Now I Sit Lake a Rabbit in the Pepper," Journal of Folklore Research, Vol. 40, No. 1.

${ }^{5}$ Terry Gunnell, "Daisies Rise to Become Oaks. The Politics of Early Folktale Collection in Northern Europe,” Journal of Folklore Research, Vol. 121, No.1. 
dan kontribusi Antonio Gramsci dalam studi cerita rakyat berbahasa Inggris. Menurutnya, cerita rakyat sering disalahpahami karena belum dibaca bersamasama dan ditanggapi dengan akal sehat dan agama, dan juga belum ada konteks diskusi tentang perbedaan diantara cerita rakyat, filsafat, dan ilmu pengetahuan. Penelitian ini juga menarik perbandingan singkat dengan karya Hans George Gadamer dalam rangka untuk mengatasi ide-ide untuk penelitian kontemporer dan merebut kembali legitimasi politik cerita rakyat kritis yang terang-terangan akan menjadi dilema politik dan penderitaan manusia.

Lebih lanjut Schwatz meneliti tentang arkeolog yang membuat perbedaan antara budaya material dan ritual budaya material sehari-hari. Memahami hubungan yang komplek, antara budaya yang material, ritual, dan kehidupan sehari-hari. Dengan menggunakan cerita rakyat yang tercatat di Skotlandia pada abad ke tujuh belas sampai abad ke dua puluh diperlukan model cerita rakyat yang kontinyu. Model itu dapat memperkaya pemahaman arkeologi makna dan keyakinan yang membentuk konteks budaya untuk artefak, fitur, situs, dan belajar. ${ }^{7}$ Duffin meneliti cerita binatang seperti batu burung elang, burung gagak, ayam jantan yang dianggap memiliki kekuatan. Selain itu, cerita-cerita rakyat di desa seringkali dijadikan tema dalam kegiatan karnaval budaya yang diselenggarakan setiap tahun oleh Dinas Pariwisata dan Kebudayaan setempat. ${ }^{8}$ Pelestarian dalam kegiatan tersebut belumlah cukup manakala belum banyak yang mendokumentasikan cerita rakyat di Kabupaten Kudus dalam bentuk buku.

Pentingnya nilai-nilai edukasi dalam cerita rakyat Sunan Muria dapat digunakan sebagai salah satu usaha menanamkan pendidikan karakter siswa di sekolah. Hal ini relevan dengan pelaksanaan kurikulum bahasa Jawa di SMA yang di dalamnya terdapat materi cerita rakyat. Dalam materi cerita rakyat tersebut, siswa diarahkan untuk mencari dan mengapresiasi cerita rakyat yang diperolehnya. Secara tidak langsung cerita rakyat yang diperoleh memberikan pembelajaran kepada siswa untuk meneladani tokoh-tokoh dalam cerita rakyat tersebut. Ini menunjukkan bahwa cerita rakyat memiliki peranan penting dalam penanaman pendidikan karakter. Sebagaimana yang diungkapkan Muslich, pendidikan karakter bertujuan meningkatkan mutu penyelenggaraan dan hasil

${ }^{6}$ Stephen Olbrys Gancarella, "Gramsci, Good Sense, and Critical Folklore Studies,” Journal of Folklore Research, Vol. 47, No. 3.

7 Amy Gazin Schwatz, "Archaeology and Folklore of Material Culture, Ritual, and Everyday Life International" Journal of Historical Archaeology, Vol. 5, No. 4.

${ }^{8}$ Christopher J. Duffin, “A Survey of Birds and Fabulous Stones,” Journal of Folklore Research, Vol. 123, No. 2 . 
pendidikan yang mangarah pada pencapaian pembentukan karakter dan akhlak mulia peserta didik secara utuh, terpadu, dan seimbang.'

Berdasarkan uraian di atas, akan diadakan penelitian Cerita Rakyat Sunan Muria di Kabupaten Kudus khususnya di kawasan Kudus bagian timur. Cerita Rakyat Sunan Muria dalam penelitian ini akan dikaji dari struktur cerita dan nilai pendidikan karakter, dengan harapan dapat memberi manfaat positif bagi masyarakat di Kabupaten Kudus.

\section{Metode}

Jenis dan desain penelitian menggunakan deskriptif kualitatif. Penelitian cerita rakyat Sunan Muria di Kabupaten Kudus ini dilaksanakan pada beberapa desa antara lain: desa Honggosoco, Hadipolo, Sadang, Pladen di Kecamatan Jekulo, dan Desa Kandangmas Kecamatan Dawe. Teknik yang digunakan dalam pengumpulan data meliputi: observasi langsung, wawancara kepada tokoh masyarakat (pemerhati budaya lokal dan juru kunci makam Sunan Muria), simak, dan analisis dokumen arsip-arsip, makalah-makalah dari buku-buku karya beberapa pengarang, petugas pada dinas, dan instansi terkait.

\section{Hasil dan Pembahasan}

Hasil

Berdasarkan penelitian cerita rakyat di lapangan, peneliti memperoleh struktur Cerita Rakyat Sunan Muria di Kabupaten Kudus antara lain sebagai berikut:

Struktur Cerita Rakyat Raden Ayu Nawangsih dan Raden Bagus Rinangku di Dukuh Masin Desa Kandangmas Kecamatan Dawe Kabupaten Kudus

\section{Tema}

Peristiwa yang diceritakan dalam cerita rakyat Raden Ayu Dewi Nawangsih dan Bagus Rinangku ini menggambarkan kisah percintaan dua orang manusia yang berjanji ingin mengarungi hidup bersama. Namun kisah percintaan dua sejoli ini tidak direstui oleh Sunan Muria.

\section{Alur}

Alur yang digunakan dalam cerita rakyat Raden Ayu Dewi Nawangsih dan Raden Bagus Rinangku adalah alur maju, karena cerita mengalir

\footnotetext{
${ }^{9}$ Masnur Muslich, Pendidikan Karakter: Menjawab Tantangan Krisis Multidimensional....
} 
disampaikan secara runtut dan menimbulkan kejadian selanjutnya. Cerita diawali dengan menggambarkan tokoh yang sangat berpengaruh dalam cerita yaitu Sunan Muria dan tokoh-tokoh yang lain. Permasalahan mulai timbul ketika hubungan antara Nawangsih dengan Rinangku tidak disukai oleh Sunan Muria. Permasalahan lebih lanjut timbul dikarenakan Cebolek menghasut Rinangku sedang memadu asmara dengan Nawangsih. Cebolek melaporkan kepada Sunan Muria seolah-olah kejadian tersebut benar-benar terjadi. Konflik kembali terjadi ketika Sunan Muria mempercayai laporan Cebolek. Pergulatan ini membuat alur cerita menjadi hidup ditambah dengan konflik-konflik lain yang melibatkan tokoh-tokoh lainnya. Konflik berakhir ketika Rinangku mati karena tidak sengaja terkena senjata panah yang dilepaskan oleh Sunan Muria.

\section{Tokoh}

Tokoh utama dalam cerita rakyat ini adalah Sunan Muria, Rinangku, dan Nawangsih. Sementara itu tokoh yang lain adalah Cebolek.

\section{Latar}

Latar dalam cerita rakyat Raden Ayu Dewi Nawangsih dan Raden Bagus Rinangku antara lain latar tempat, waktu, dan suasana. Latar tempat diantaranya yaitu padepokan Sunan Muria di lereng Gunung Muria, sawah di Dukuh Masin dimana Nawangsih dan Rinangku dimakamkan. Latar waktu ditunjukkan ketika Rinangku melakukan kesalahan karena membiarkan padi yang telah menguning dimakan burung, kemudian keesokan harinya Rinangku bisa mengembalikan padi-padi menguning kembali.

Pada bagian latar suasana cerita rakyat ini terdapat suasana senang, tegang, dan sedih. Suasana senang ditunjukkan ketika Nawangsih melihat laki-laki tampan bernama Rinangku yang membuatnya jatuh cinta. Nawangsih juga merasa senang ketika disuruh ayahnya mengirim makanan kepada Rinangku di sawah. Suasana tegang terjadi ketika Sunan Muria marah kepada Rinangku karena tidak bisa menjaga padi dengan baik. Ketegangan juga terjadi ketika Sunan Muria mengarahkan anak panah ke tubuh Rinangku dengan tujuan menakut-nakuti agar Nawangsih mau menjauh dari Rinangku. Namun anak panah tersebut tidak sengaja melukai perut Rinangku hingga tembus ke punggung dan menemui ajal. Sementara itu, penggambaran suasana sedih ditunjukkan ketika Rinangku dan Nawangsih menemui ajalnya. 


\section{Amanat}

Cerita rakyat Raden Ayu Dewi Nawangsih dan Raden Bagus Rinangku ini ditemukan beberapa amanat bagi generasi muda antara lain: sifat Sunan Muria yang kurang bijak dalam mensikapi permasalahan percintaan Nawangsih dengan Rinangku. Sebagai orang tua yang bijaksana seharusnya memberikan kesempatan kepada anaknya untuk memilih calon pendamping hidup sendiri, bukan menjodohkan dengan orang yang tidak dicintainya.

Nawangsih juga harus mengetahui batasan-batasan hubungan dengan lawan jenis yang belum sah menjadi suaminya. Begitu juga dengan Rinangku, sebagai seorang santri ia harus mengerti dan memahami betul perintah dari gurunya sehingga tidak akan terjadi salah paham. Sementara itu, sifat Cebolek yang menghasut dan mencemburui hubungan Rinangku dengan Nawangsih tidak patut dicontoh karena dapat menyengsarakan orang lain. Peristiwa kematian Nawangsih dan Rinangku merupakan pembelajaran hidup bahwa manusia di dunia ini akan menemui ajal. Manakala ada sanak keluarga yang meninggal, sebaiknya tidak terlarut dalam kesedihan yang mendalam.

\section{Struktur Cerita Rakyat Bulusan di Dukuh Sumber Desa Hadipolo Kecamatan Jekulo Kabupaten Kudus}

\section{Tema}

Peristiwa yang diceritakan dalam cerita rakyat Bulusan di Dukuh Sumber Desa Hadipolo, Kecamatan Jekulo, Kabupaten Kudus ini menggambarkan dua orang manusia yang setia kepada gurunya yang bernama Mbah Dudo.

\section{Alur}

Alur yang digunakan dalam cerita rakyat Bulusan adalah alur maju, karena cerita mengalir disampaikan secara runtut dan menimbulkan kejadian selanjutnya. Cerita diawali dengan mengisahkan tentang Mbah Dudo, Umara dan Umari. Permasalahan mulai timbul ketika Umara dan Umari berubah menjadi Bulus. Umara dan Umari meminta tolong Sunan Muria untuk mengembalikan mereka seperti semula, namun Sunan Muria tidak bisa menuruti kemauan mereka karena kejadian tersebut sudah menjadi kehendak Tuhan. Konflik berakhir ketika Umara dan Umari mau menerima kejadian yang dialaminya. 


\section{Tokoh}

Tokoh utama dalam cerita rakyat ini adalah Sunan Muria, Mbah Dudo, Umara, dan Umari. Sunan Muria merupakan tokoh penyebar agama Islam di tanah Jawa, khususnya lereng gunung muria kabupaten Kudus. Nama asli Sunan Muria adalah Raden Umar Said.

Sementara itu, Mbah Dudo adalah seorang alim ulama penyebar agama Islam yang berasal dari Mataram. Beliau merupakan sahabat Sunan Muria dalam menyebarkan agama Islam. Selain menjadi alim ulama, beliau juga ahli nujumnya Syeh Subakir dari Arab. Dalam menyebarkan agama Islam, Mbah Dudo mempunyai niat untuk mendirikan pesantren di kaki Pegunungan Muria.

Mbah Dudo mempunyai murid yang bernama Umara dan Umari. Kedua murid Mbah Dudo tersebut sangat taat dan setia kepadanya. Kesetiaan itu terlihat ketika Mbah Dudo menyuruh Umara dan Umari untuk bercocok tanam, keduanya sangat gembira dan akan segera melaksanakan tugasnya.

\section{Latar}

Latar dalam cerita rakyat Bulusan antara lain latar tempat, waktu, dan suasana. Latar tempat diantaranya yaitu pesanggrahan (tempat tinggal) Mbah Dudo, sawah Maja, sawah Praseman, daerah Togok, dan Sumber. Tempattempat tersebut merupakan daerah dimana peristiwa-peristiwa saling berkaitan. Latar waktu ditunjukkan ketika Umara dan Umari sedang ndaut atau mengambil bibit padi di sawah pada malam hari. Sementara itu, Sunan Muria juga melihat apa yang dilakukan Umara dan Umari pada malam hari.

Pada bagian latar suasana cerita Bulusan ini terdapat suasana senang dan sedih. Suasana senang digambarkan ketika Umara dan Umari sangat gembira mendapat tugas untuk bercocok tanam. Suasana sedih dalam cerita rakyat ini ditunjukkan ketika Mbah Dudo melihat kedua muridnya berubah wujud menjadi Bulus. Kesedihan juga dirasakan oleh Umara dan Umari ketika mereka berubah wujud menjadi bulus. Keduanya juga merasakan kesedihan karena harus hidup di air dan susah untuk mencari makan.

\section{Amanat}

Berdasarkan cerita rakyat Bulusan ini ditemukan beberapa amanat bagi generasi muda antara lain: Kekhilafan Mbah Dudo ketika menyuruh muridnya untuk bercocok tanam di malam hari. Padahal malam itu 
bertepatan dengan malam Nuzulul Qur'an yang seharusnya digunakan untuk mengaji. Sebagai seorang guru, alangkah lebih baik jika Mbah Dudo memberikan pemahaman bahwa melaksanakan ibadah puasa bukanlah penghalang untuk menjalankan aktivitas sehari-hari.

Sebagai seorang murid, alangkah lebih baik jika Umara dan Umari memberikan saran atau pendapat kepada gurunya, karena Mbah Dudo juga manusia biasa yang tidak terlepas dari kekhilafan.

Kesetiaan dan ketaatan Umara dan Umari terhadap gurunya dapat dijadikan contoh dalam kehidupan kita. Guru merupakan panutan yang berasal dari kerata basa Jawa "digugu lan ditiru". Namun jika ada seorang guru yang mengajarkan kejelekan, tidak sepatutnya dicontoh oleh muridmuridnya. Ujian penderitaan yang dialami oleh Umara dan Umari dapat dijadikan pembelajaran, bahwa dalam menjalankan sesuatu harus dipikir terlebih dahulu dengan matang. Manusia pun tidak bisa terlepas dari ujian Yang Maha Kuasa karena dengan ujian tersebut, manusia menjadi lebih taat kepada-Nya.

\section{Struktur Cerita Rakyat Mbah Onggowongso di Dukuh Onggowangsan Desa Honggosoco Kecamatan Jekulo Kabupaten Kudus}

\section{Tema}

Peristiwa yang diceritakan dalam cerita rakyat Mbah Onggowongso di Dukuh Onggowangsan Desa Honggosoco, Kecamatan Jekulo, Kabupaten Kudus ini menggambarkan seorang santri yang taat dan patuh melaksanakan perintah Sunan Muria untuk menyebarkan agama Islam di kaki gunung Muria.

\section{Alur}

Alur yang digunakan dalam cerita rakyat Mbah Onggowongso adalah alur maju, karena cerita mengalir disampaikan secara runtut dan menimbulkan kejadian selanjutnya. Cerita diawali dengan mengisahkan tentang Mbah Onggowongso yang ditugasi oleh Sunan Muria untuk berdakwah di kaki Gunung Muria. Dahulu di kaki Gunung Muria masih berupa hutan belantara. Perjalanan Mbah Onggowongso menuju kaki gunung dengan menunggang seekor kuda. Akhirnya Mbah Onggowongso sampai di kaki gunung Muria dan beristirahat di sekitar sungai. Kudanya dibiarkan berada di pinggir sungai supaya leluasa minum air, kemudian beliau kembali ke tempat dimana beliau berteduh dan beristirahat. Tempat 
peristirahatan tersebut digunakan Mbah Onggowongso untuk lelaku. Beliau menyebarkan biji-biji tasbih kemudian mengambilnya kembali. Biji-biji tasbih tersebut disebarkan berulang-ulang. Permasalahan mulai timbul ketika Mbah Onggowongso sedang lelaku, beliau mengetahui kuda yang berada di bibir sungai terseyok-seyok karena kakinya terperosok ke dalam tanah. Konflik diri Mbah Onggowongso berkahir setelah kaki kudanya bisa terangkat, tiba-tiba bekas kaki kuda tersebut keluar sumber air. Mbah Onggowongso berkata: "Kelak makmurnya zaman, daerah ini bernama Sumur Bandung”.

\section{Tokoh}

Tokoh utama dalam cerita rakyat ini adalah Sunan Muria dan Mbah Onggowongso. Sunan Muria merupakan tokoh penyebar agama Islam di tanah Jawa, khususnya lereng gunung muria kabupaten Kudus. Nama asli Sunan Muria adalah Raden Umar Said.

Sementara itu, Mbah Onggowongso adalah murid sekaligus pekathik atau orang yang memelihara kuda Sunan Muria. Beliau adalah murid yang taat dan setia terhadap Sunan Muria. Sikap taat dan setia digambarkan ketika Mbah Onggowongso pergi melaksanakan perintah Sunan Muria untuk menyebarkan agama Islam di kaki gunung Muria.

\section{Latar}

Latar dalam cerita rakyat Mbah Onggowongso hanya terdapat latar tempat yaitu tempat beristirahat Mbah Onggowongso dan sungai tempat kuda beristirahat. Kedua tempat tersebut merupakan daerah dimana peristiwa-peristiwa saling berkaitan.

\section{Amanat}

Cerita rakyat Mbah Onggowongso ini memiliki beberapa amanat bagi generasi muda antara lain: Sebagai seorang murid, Mbah Onggowongso bersedia melaksanakan tugas gurunya dengan baik. Sikap tersebut menunjukkan kesetiaan dan ketaatan murid kepada guru. Sebagai seorang pekathik, Mbah Onggowongso diberi kepercayaan dan tanggungjawab untuk merawat kuda Sunan Muria dengan baik. Ketika kudanya terseyok-seyok karena kakinya terperosok ke dalam tanah, Mbah Onggowongso bergegas menyalamatkan kuda tersebut. Perbuatan Mbah Onggowongso sepatutnya dicontoh dalam kehidupan sehari-hari. Utamanya untuk menanamkan pendidikan pekerti terhadap anak. 
Struktur Cerita Rakyat Joko Satriyan di Desa Sadang Kecamatan Jekulo Kabupaten Kudus

Tema

Peristiwa yang diceritakan dalam cerita rakyat Joko Satriyan ini menggambarkan kisah percintaan Joko Satriyan dengan Roro Riyep. Nyai Wati ingin menjadikan Joko Satriyan sebagai menantu. Namun, Sunan Muria tidak menyetujui hubungan mereka karena perbedaan status sosial. Sunan Muria seorang ulama dan tokoh masyarakat, sedangkan Nyai Wati hanyalah seorang janda beranak satu yang hidup dalam kesederhanaan.

\section{Alur}

Alur yang digunakan dalam cerita rakyat Joko Satriyan adalah alur maju, karena cerita mengalir disampaikan secara runtut dan menimbulkan kejadian selanjutnya. Cerita diawali dengan menggambarkan tokoh Sunan Muria, Joko Satriyan, Nyai Wati dan Roro Riyep. Permasalahan mulai timbul ketika Sunan Muria tidak mau merestui hubungan Joko Satriyan dengan Roro Riyep. Joko Satriyan bersikukuh ingin tetap melanjutkan hubungannya dengan Nawangsih dengan cara memberi pengertian dan pemahaman kepada Sunan Muria. Konflik mulai menurun ketika Sunan Muria bisa menerima penjelasan Joko Satriyan. Akhirnya Sunan Muria merestui hubungan Joko Satriyan dengan Roro Riyep.

\section{Tokoh}

Tokoh utama dalam cerita rakyat ini adalah Sunan Muria dan Joko Satriyan. Sementara itu tokoh yang lain adalah Roro Riyep dan Nyai Wati. Sunan Muria merupakan tokoh penyebar agama Islam di tanah Jawa, khususnya lereng gunung Muria kabupaten Kudus. Nama asli Sunan Muria adalah Raden Umar Said.

Joko Satriyan adalah putra terakhir Sunan Muria. Dia senang dengan mikat burung di sawah. Kesukaan berburu burung tersebut membuatnya bertemu dengan seorang wanita cantik bernama Roro Riyep. Setelah hidup bersama dengan Roro Riyep, dia melanjutkan cita-cita ayahnya menyebarkan agama Islam di daerah yang sekarang bernama desa Sadang. Sementara itu, Roro Riyep adalah wanita lugu dan penurut yang dicintai oleh Joko Satriyan. Dia merupakan wanita cantik anak seorang janda yang bernama Nyai Wati. Nyai Wati tergolong orang mampu, namun dia tetap hidup dalam kesederhanaan. Dia sangat menyayangi Roro Riyep anak semata wayangnya. 
Kebaikan Nyai Wati menjadikan Joko Satriyan betah dan nyaman tinggal di rumah Nyai Wati.

\section{Latar}

Latar dalam cerita rakyat Joko Satriyan antara lain latar tempat, waktu, dan suasana. Latar tempat di antaranya yaitu padepokan Sunan Muria di lereng Gunung Muria, sawah tempat mikat burung, dan rumah Nyai Wati. Latar waktu ditunjukkan menjelang sore ketika Joko Satriyan berjalan menuju rumah Nyai Wati meminta air minum. Selain itu latar waktu juga disebutkan ketika esok harinya Joko Satriyan berniat ingin pulang ke rumah meminta pendapat dan restu dari ayahnya.

Pada bagian latar suasana cerita rakyat ini terdapat suasana senang dan sedih. Suasana senang ditunjukkan ketika Joko Satriyan melihat perkutut putih yang memakai gelang emas, kendi emas, dan wanita cantik yang bernama Roro Riyep. Suasana senang juga disebutkan ketika Joko Satriyan menikah dan hidup bahagia bersama kekasihnya. Selain itu, suasana senang juga diperlihatkan ketika Joko Satriyan membawa kabar gembira karena akan segera menikahi Roro Riyep. Sementara itu, suasana sedih diperlihatkan ketika Joko Satriyan kecewa karena Sunan Muria tidak menyetujui hubungannya dengan Roro Riyep.

\section{Amanat}

Berdasarkan cerita rakyat Joko Satriyan ini ditemukan beberapa amanat bagi generasi muda antara lain: Sifat Joko Satriyan yang patuh, taat, dan sopan terhadap orang tua patut dijadikan contoh bagi generasi muda. Sebagai seorang anak, Joko Satriyan juga mengetahui batasan-batasan hubungan dengan lawan jenis yang belum sah menjadi istrinya, karena akan menimbulkan fitnah. Sikap Joko Satriyan yang mau memberikan pengertian dan pemahaman kepada ayahnya sepatutnya dijadikan contoh, karena pendapat anak sebaiknya didengarkan dan dihargai sebagaimana mestinya.

Pada awalnya Sunan Muria tidak menyetujui hubungan Joko Satriyan dengan Roro Riyep. Setelah Joko Satriyan memberikan pengertian dan pemahaman kepada ayahnya, Sunan Muria mau menerima Roro Riyep menjadi menantunya. Sebagai orang tua yang bijak, sebaiknya memberi kesempatan kepada anaknya berpendapat dan memilih calon pendamping hidup sendiri. Kisah percintaan Joko Satriyan dan Roro Riyep merupakan pembelajaran hidup bahwa antara anak dan orang tua harus saling 
memahami satu sama lain, sehingga tidak akan terjadi kesalahpamahan dikemudian hari.

\section{Struktur Cerita Rakyat Mbah Makdum Nata Kusuma Aji di Desa Pladen Kecamatan Jekulo Kabupaten Kudus}

\section{Tema}

Peristiwa yang diceritakan dalam cerita rakyat Mbah Makdum Nata Kusuma Aji di Desa Pladen, Kecamatan Jekulo, Kabupaten Kudus ini menggambarkan seorang santri yang rajin dan tekun dalam menuntut ilmu. Selain itu beliau sangat berbakti dan patuh melaksanakan perintah Sunan Muria untuk menyebarkan agama Islam di kaki gunung Muria.

\section{Alur}

Alur yang digunakan dalam cerita rakyat Mbah Makdum Nata Kusuma Aji adalah alur maju, karena cerita mengalir disampaikan secara runtut dan menimbulkan kejadian selanjutnya. Cerita diawali dengan mengisahkan tentang Mbah Makdum Nata Kusuma Aji sebagai anak raja Paku Alam II. Permasalahan mulai timbul ketika Mbah Makdum Nata Kusuma Aji ingin meninggalkan kerajaan karena tidak menyukai kesewenang-wenangan Belanda menjajah dan membunuh rakyat. Beliau belum bisa berbuat apa-apa karena masih anak-anak. Untuk meredam konflik batin dalam dirinya, Mbah Makdum Nata Kusuma Aji pergi dari kerajaan untuk memperdalam ilmu agama Islam kepada Sunan Muria. Konflik Mbah Makdum Nata Kusuma Aji berakhir setelah berhasil menemui Sunan Muria untuk memperdalam agama Islam.

\section{Tokoh}

Tokoh utama dalam cerita rakyat ini adalah Sunan Muria dan Mbah Makdum Nata Kusuma Aji. Sunan Muria merupakan tokoh penyebar agama Islam di lereng gunung muria kabupaten Kudus. Mbah Makdum Nata Kusuma Aji adalah salah satu santri kesayangan Sunan Muria. Beliau merupakan keturunan dari Kerajaan Mataram yaitu putra pertama dari Sri Paku Alam II. Ketika menginjak dewasa Mbah Makdum Nata Kusuma Aji tidak suka melihat kesewenang-wenangan Belanda, kemudian beliau pergi meninggalkan kerajaan dan bergelar Pangeran Pati. Beliau seorang santri yang rajin dan tekun dalam menuntut ilmu. Selain itu juga sangat berbakti dan patuh melaksanakan perintah Sunan Muria untuk menyebarkan agama Islam di kaki gunung Muria. 


\section{Latar}

Latar dalam cerita rakyat Mbah Makdum Nata Kusuma Aji terdapat latar tempat yaitu Padepokan Gunung Muria dan tempat dimana beliau menyebarkan agama Islam (desa Pladen). Kedua tempat tersebut merupakan daerah dimana Mbah Makdum Nata Kusuma Aji belajar dan mengamalkan ilmu agama Islam.

Pada bagian latar waktu ditunjukkan ketika Mbah Makdum Nata Kusuma Aji tidak suka melihat kesewenang-wenangan zaman penjajahan Belanda. Selain itu, latar waktu disebutkan ketika suatu hari Sunan Muria berkunjung ke tempat Mbah Makdum Nata Kusuma Aji dan menanyakan nama desa yang ditempati.

Latar suasana dalam cerita rakyat ini terdapat suasana senang yaitu Sunan Muria sangat senang mempunyai santri yang rajin, tekun, patuh, dan berbakti seperti Mbah Makdum Nata Kusuma Aji.

\section{Amanat}

Cerita rakyat Mbah Makdum Nata Kusuma Aji ini memiliki beberapa amanat bagi generasi muda antara lain: Sebagai seorang murid, Makdum Nata Kusuma Aji adalah santri yang rajin, tekun, patuh, dan berbakti kepada gurunya. Perbuatan Mbah Makdum Nata Kusuma Aji sepatutnya dicontoh dalam kehidupan sehari-hari. Utamanya untuk menanamkan pendidikan pekerti terhadap anak di sekolah.

\section{Pembahasan}

Keterkaitan Antar Unsur yang Membangun Cerita Rakyat Sunan Muria di Kabupaten Kudus

Seperti yang disampaikan oleh Winarni dalam Dwi menyebutkan bahwa analisis struktur bertujuan untuk membongkar dan memaparkan secara mendalam dan secermat-cermatnya keterkaitan antara unsur-unsur karya sastra untuk menghasilkan makna secara komprehensif. ${ }^{10}$ Demikian juga dalam cerita rakyat Sunan Muria di Kabupaten Kudus memiliki unsur-unsur yang

${ }^{10}$ Trinil Turistiani Dwi, "Struktur Alur dan Bentuk Konflik yang Membangun Novel Saman Karya Ayu Utami,” Jurnal Pena Indonesia, Vol. 3, No. 2. 
membangun di dalamnya meliputi tema, alur, tokoh, latar, dan amanat. Semua unsur tersebut mendukung cerita awal sampai akhir. Unsur yang satu dengan yang lain saling menentukan dan memengaruhi menjadi satu kesatuan yang utuh. Seperti yang diungkapkan Nurgiyantoro, stuktur cerita mengacu pada hubungan antarunsur intrinsik yang bersifat timbal balik, saling menentukan, saling memengaruhi yang secara bersama membentuk satu kesatuan yang utuh. ${ }^{11}$

Secara umum lima cerita rakyat Sunan Muria di Kabupaten Kudus berupa rangkaian peristiwa yang terjadi berdasarkan urutan waktu dari satu cerita/ peristiwa ke peristiwa berikutnya. Rangkaian cerita bersifat kronologis dan menunjukkan sebab akibat dari urutan awal, tengah hingga akhir cerita. Seperti pada cerita Raden Ayu Dewi Nawangsih dan Raden Bagus Rinangku yang diceritakan mulai dari pengenalan tokoh, hubungan antartokoh, peristiwa, tempat, waktu, konflik yang dialami antartokoh, dan akhir dari cerita merupakan unsur yang saling berkaitan satu sama lain. Begitu juga dengan cerita rakyat Sunan Muria yang lain seperti cerita rakyat Bulusan, Mbah Onggowongso, Joko Satriyan, dan Mbah Makdum Nata Kusuma Aji menunjukkan adanya keterkaitan antar unsur yang satu dengan unsur yang lain.

Tema yang terdapat pada cerita rakyat Sunan Muria di Kabupaten Kudus berisi perjalanan seorang tokoh yang di dalamnya terdapat hubungan antara murid dengan guru dan tentang percintaan. Berdasarkan isi maupun tema dari cerita rakyat Sunan Muria di Kabupaten Kudus tersebut dapat diklasifikasikan dalam bentuk legenda keagamaan, legenda setempat, dan legenda perseorangan.

Pada alur cerita rakyat Sunan Muria di Kabupaten Kudus menggunakan alur maju. Alur maju menggambarkan pelaku dari awal kemudian disusul peristiwa-yang satu menyebabkan peristiwa berikutnya secara berurutan hingga akhir cerita sehingga jalan cerita dari awal hingga akhir mudah dipahami. Seperti yang dijelaskan Waluyo menyebutkan bahwa teori alur meliputi: (1) paparan awal cerita (exposition), (2) mulai dari problem (incitingmoment), penanjakan konflik (rising action), (4) konflik yang semakin (complication), (5) konflik menurun (falling action), dan (6) penyelesaian (denouement). ${ }^{12}$

Kajian strukturalisme tentang tokoh dalam cerita rakyat Sunan Muria di Kabupaten Kudus dapat dikelompokkan pada tokoh utama dan tokoh pendukung. Tokoh utama diceritakan lebih banyak dan terkesan mendominasi jalannya cerita. Sementara itu tokoh pendukung intensitas kemunculannya jauh

\footnotetext{
${ }^{11}$ Burhan Nurgiantoro, Dasar Dasar Kajian Fiksi, (Yogyakarta: Usaha Mahasiswa, 2005).

${ }^{12}$ Herman J. Waluyo, Apresiasi Prosa dan Drama, (Surakarta: UNS Press, 2002).
} 
lebih sedikit. Karakter tokoh atau penokohan yang dimunculkan merupakan karakter baik dan buruk. Sesuai dengan Nurgiyantoro yang menyatakan tokoh menunjukkan pelaku cerita, sedangkan penokohan merupakan pelukisan gambaran yang jelas tentang seseorang yang ditampilkan dalam sebuah cerita. ${ }^{13}$

Pada kajian strukturalisme latar cerita rakyat Sunan Muria di Kabupaten Kudus lebih menonjolkan latar tempat yang selalu berganti dari tempat yang satu ke tempat yang lain. Seperti pada cerita rakyat Bulusan, latar tempat menjadi bagian penting terjadinya peristiwa berikutnya. Latar tempat tersebut antara lain: hutan, sawah Maja, sawah Praseman, sumber air, dan daerah Togok. Hal ini sesuai dengan pernyataan Bahtiar yang menyatakan penyajian latar sebagai pemerjelas dari awal sampai akhir cerita. ${ }^{14}$

Berdasarkan isi cerita rakyat Sunan Muria di Kabupaten Kudus ditemukan amanat yang dapat dijadikan sebagai bahan pembelajaran, baik yang tersurat (eksplisit) maupun tersirat (implisit). Seperti amanat pada cerita rakyat Raden Ayu Dewi Nawangsih dan Raden Bagus Rinangku yang memberikan pembelajaran kepada manusia bahwa sebagai orang tua yang bijaksana seharusnya memberikan kesempatan kepada anaknya untuk memilih calon pendamping hidup sendiri, bukan menjodohkan dengan orang yang tidak dicintainya. Sebagai seorang anak, Nawangsih juga harus mengetahui batasanbatasan hubungan dengan lawan jenis yang belum sah menjadi suaminya. Begitu juga dengan Rinangku, sebagai seorang santri ia harus mengerti dan memahami betul perintah dari gurunya sehingga tidak akan terjadi salah paham. Sementara itu, sifat Cebolek yang menghasut dan mencemburui hubungan Rinangku dengan Nawangsih tidak patut dicontoh karena dapat menyengsarakan orang lain. Peristiwa kematian Nawangsih dan Rinangku merupakan pembelajaran hidup bahwa manusia di dunia ini akan menemui ajal. Manakala ada sanak keluarga yang meninggal, sebaiknya tidak terlarut dalam kesedihan yang mendalam. Seperti yang diungkapkan Waluyo menyatakan amanat merupakan pesan yang disajikan secara eksplisit (tersurat) dan implisit (tersirat) melalui dialog atau percakapan antartokoh. ${ }^{15}$ Melalui dialog tersebut akan mudah ditangkap maknanya oleh pembaca. Selain itu amanat juga dapat dipahami melalui perenungan atau pemikiran atas apa yang terjadi dalam cerita.

\footnotetext{
${ }^{13}$ Burhan Nurgiantoro, Dasar Dasar Kajian Fiksi....

${ }^{14}$ Ahmad Bahtiar, "Sikap Pengarang dalam Novel Palawidja Karya Karim Halim dan Kembang Jepung Karya Remi Silado: Sebuah Bandingan,” Jurnal Adabiyat: Jurnal Bahasa dan Sastra, Vol. 4, No. 1.

${ }^{15}$ Herman J. Waluyo, Apresiasi Prosa dan Drama...
} 
Amanat dapat bersifat interpretatif artinya setiap orang mempunyai penafsiran makna yang berbeda dengan yang lain.

\section{Nilai Pendidikan Karakter Cerita Rakyat Sunan Muria di Kabupaten Kudus}

\section{Nilai Religius}

Nilai religius yang terdapat dalam cerita rakyat Sunan Muria antara lain seorang santri yang patuh melaksanakan tugas guru untuk menyebarkan agama Islam. Hubungan antara guru dan murid merupakan hubungan horisontal yang berarti interaksi antar sesama manusia yang saling membutuhkan satu sama lain. Hubungan vertikal antara manusia dengan Tuhan ditunjukkan ketika seorang manusia melaksanakan perintah Tuhan untuk mengamalkan ilmu yang dimilikinya. Nilai religius itu telah dilaksanakan oleh tokoh-tokoh dalam cerita rakyat Sunan Muria seperti Sunan Muria, Mbah Onggowongso, Joko Satriyan, dan Mbah Makdum Nata Kusuma Aji. Seperti yang disampaikan oleh Purwandi dkk., menjelaskan jika nilai religius secara etimologi berasal dari bahasa latin relego, bertujuan untuk menimbang kembali atau prihati terhadap suatu hal. Religi adalah wujud dari kesadaran yang bergejolak secara mendalam di lubuk hati manusia sebagai human nature. ${ }^{16}$

Pendapat lain dari Putri menjelaskan jika karya sastra yang memiliki nilai-nilai religius menjadi urgensi untuk membangun iman di zaman modern. Hadirnya unsur nila-nilai religius dan keagamaan dalam sastra menunjukkan keberadaan sastra itu sendiri. ${ }^{17}$ Dengan kata lain, suatu karya sastra memiliki nilai yang terkandung di dalamnya secara implisit. Nilai tersebut dapat diimplementasikan untuk kegiatan belajar-mengajar di sekolah. ${ }^{18}$

\section{Nilai Kejujuran}

Nilai kejujuran terdapat pada cerita rakyat Joko Satriyan yaitu ketika Joko Satriyan menceritakan dengan jujur kejadian yang dialaminya di rumah Nyai Wati. Kejujuran juga dilakukan oleh Mbah Makdum Nata Kusuma Aji

${ }^{16}$ Eko Purwandi dkk., "Nilai Religius dan Nilai Sosial dalam Materi Pembelajaran Sastra (Cerpen) pada Buku Teks Bahasa Indonesia SMP/MTS Kelas VIII," Jurnal Ilmiah KORPUS, Vol.2, No.2

${ }^{17}$ Nazella S. Putri dan Ali Mustofa, "Nilai Religius dalam Novel Assalamulaikum Beijing Karya Asma Nadia dan Implikasinya," Jurnal Kata: (Bahasa, Sastra dan Pembelajarannya), Vol. 6, No. 1.

${ }^{18}$ Novi Diah Haryanti, "Bidadari dan Si Penggoda Representasi Tokoh-Tokoh Perempuan dalam Novel Student Hidjo,” Jurnal Dialektika, Vol. 4, No. 1. 
ketika menjawab dengan jujur pertanyaan Sunan Muria mengenai nama desa yang ditempati Mbah Makdum Nata Kusuma Aji. Disampaikan oleh Messi (2017) jika dalam implementasi nilai-nilai kejujuran menuntut tata kehidupan sosial yang merealisasikan nilai-nilai tersebut. Selaras dengan hasil penelitian, bahwa tata kehidupan sosial dikisahkan secara runtut dan menyeluruh lewat susunan cerita-cerita tentang Sunan Muria.

\section{Nilai Toleransi}

Pada cerita rakyat Sunan Muria, sikap toleransi ditunjukkan oleh Sunan Muria ketika berkenan menerima pengertian dan pemahaman dari Joko Satriyan. Temuan nilai toleransi di dalam cerita rakyat Sunan Muria selaras dengan pendapat Kesuma yang menyatakan nilai toleransi mencerminkan sikap dan tindakan yang menghargai perbedaan agama, suku, etnis, pendapat, sikap, dan tindakan orang lain yang berbeda dari diri pribadi. ${ }^{19}$ Ini berarti menghormati dan belajar dari orang lain, menghargai perbedaan, sehingga tercapai kesamaan sikap. Hal tersebut menjadi salah satu bidang kajian dalam penelitian selanjutnya, bahwa cerita rakyat Sunan Muria harus dibukukan, seperti yang disampaikan oleh Fatmawati dkk., menjelaskan jika belum ada penelitian yang mengembangkan buku cerita edukasi berbasis karakter toleransi yang secara eksplisit mengenalkan pendidikan multikultural. ${ }^{20}$

Usman menyampaikan jika keberadaan nilai-nilai toleransi sebagai nilai fundamental yang saat ini sangat dibutuhkan untuk membangun dan memperkokoh kohesi sosial dalam masyarakat yang multikultur seperti Indonesia. Maka cerita Sunan Muria sangat perlu untuk diintegrasikan dalam kehidupan sehari-hari sebagai cerita untuk menuturkan penggambaran nilai toleransi secara konkret. ${ }^{21}$

\section{Nilai Disiplin}

Pada cerita rakyat Sunan Muria terdapat nilai disiplin antara lain yang dilakukan oleh Raden Bagus Rinangku, Raden Ayu Dewi Nawangsih, Mbah

\footnotetext{
${ }^{19}$ Dharma Kesuma, Pendidikan Karakter: Kajian Teori dan Praktik di Sekolah, Bandung: PT. Remaja Rosdakarya, 2012.

${ }^{20}$ Laila Fatmawati dkk., "Buku Cerita Edukatif Berbasis Karakter Toleransi Sebagai Inovasi Mengenalkan Pendidikan Multikultural,” Jurnal Penelitian Pendidikan, Vol. 35, No. 2.

21 Muhammad Usman dan Anton Widyanto, "Internalisasi Nilai-Nilai Toleransi dalam Pembelajaran Pendidikan Agama Islam di SMA Negeri 1 Lhokseumawe Aceh Indonesia,” Dayah: Journal of Islamic Education, Vol. 2, No. 1.
} 
Onggowongso, dan Mbah Makdum Nata Kusuma Aji yang taat dan patuh terhadap perintah yang diberikan oleh Sunan Muria. Hal ini sesuai dengan Lickona yang menyatakan disiplin merupakan perbuatan tertib dan teratur yang mengajarkan untuk tidak memperturutkan kehendak hati yang cenderung melakukan perbuatan merendahkan atau merusak diri. ${ }^{22}$ Seperti yang disampaikan Lickona, dalam penelitian Bahtiar menjelaskan jika nilainilai disiplin dapat membantu anak untuk mengembangkan kontrol diri, serta dalam mengevaluasi perilaku yang salah lalu mengoreksinya. ${ }^{23}$ Disiplin tidak bukan dilatih lewat kekerasan. Karena disiplin yang benar dan proporsional terwujud jika disiplin itu diterapkan dengan penuh kesadaran dan kasih sayang. Apabila disiplin diterapkan dengan emosi, amarah, dan kekerasan, maka yang muncul bukan disiplin yang baik, namun disiplin yang terpaksa.

\section{Nilai Kerja Keras}

Pada cerita rakyat Sunan Muria terdapat nilai kerja keras antara lain yang dilakukan oleh Mbah Onggowongso, Mbah Makdum Nata Kusuma Aji, dan Raden Bagus Rinangku dalam menjalankan perintah Sunan Muria. Selaras dengan penelitian dari Sulastri et.al. (2017) menjelaskan jika kerja keras adalah bentuk kegigihan seseorang dalam berusaha untuk memperoleh sesuatu yang ingin dicapai. Impelementasi nilai kerja keras pada karakter masing-masing individu menjadi urgensi, bertujuan memperbaiki kehidupan bangsa Indonesia. ${ }^{24}$ Kerja keras bukan berarti bekerja sampai tuntas lalu berhenti, istilah yang dimaksud adalah pada visi besar yang harus dicapai untuk kebaikan manusia serta lingkungannya.

\section{Nilai Mandiri}

Pada cerita rakyat Sunan Muria terdapat nilai mandiri antara lain yang dilakukan oleh Mbah Onggowongso, Mbah Makdum Nata Kusuma Aji, dan Raden Bagus Rinangku dalam menjalankan perintah Sunan Muria. Seperti yang disampaikan oleh Nasution, kemandirian adalah wujud kemampuan untuk mengelola semua yang dimilikinya sendiri yaitu mengetahui bagaimana mengatur waktu, berjalan, dan berpikir secara mandiri disertai

${ }^{22}$ Thomas Lickona, Pendidikan Karakter: Panduan Lengkap Mendidik Siswa Menjadi Pintar dan Baik, (Bandung: Nusa Media, 2013).

${ }^{23}$ Ahmad Bahtiar, "Sikap Pengarang dalam Novel Palawidja Karya Karim Halim dan Kembang Jepung Karya Remi Silado: Sebuah Bandingan,” ...

${ }^{24}$ Saptiana Sulastri dan Al Ashadi Alimin, "Nilai Pendidikan Karakter Kerja Keras Dalam Novel 2 Karya Donny Dhirgantoro,”Jurnal Pendidikan Bahasa, Vol. 6, No. 2. 
dengan kemampuan dalam mengambil keputusan dan memecahkan masalah. Nilai mandiri tersebut mampu diadaptasi dari cerita Sunan Muria, yaitu para tokoh dalam menjalankan keputusan ketika menjalankan perintah Sunan Muria. $^{25}$

\section{Nilai Demokratis}

Pada cerita rakyat Sunan Muria terdapat nilai demokratis antara lain yang dilakukan oleh Sunan Muria yang menghargai pendapat Joko Satriyan dalam memilih pasangan hidup. Hal ini sesuai dengan pernyataan Lickona yang menyatakan demokratis adalah sikap yang memberi kesempatan dan menghargai orang lain. ${ }^{26}$

\section{Nilai Bersahabat/ Komunikatif}

Pada cerita rakyat Sunan Muria terdapat nilai bersahabat/ komunikatif antara lain yang dilakukan Sunan Muria ketika mengunjungi sahabatnya yang bernama Mbah Dudo pada malam Nuzulul Qur'an. Sunan Muria juga mengunjungi Mbah Makdum Nata Kusuma Aji dalam rangka bersilaturahmi dan menanyakan nama desa yang ditempati oleh Mbah Makdum Nata Kusuma Aji. Hal ini sesuai dengan dengan pernyataan Kesuma yang menyatakan nilai bersahabat adalah sikap yang menunjukkan hubungan baik, saling berbagi, dan akrab dengan orang lain. ${ }^{27}$

\section{Nilai Cinta Damai}

Nilai cinta damai mencerminkan sikap merasa senang, tenang, dan bahagia dengan sesamanya. Nilai cinta damai dalam cerita rakyat Sunan Muria terdapat pada cerita rakyat Raden Ayu Nawangsih. Sikap cinta damai tersebut ditunjukkan oleh Rinangku ketika mengalahkan perampok. Rinangku tidak menyukai perbuatan keji perampok yang merampas kebahagian dan ketenangan masyarakat pada saat itu. Hal ini menunjukkan bahwa Rinangku memiliki sikap cinta damai kepada sesama manusia. Temuan nilai cinta damai di dalam cerita rakyat Sunan Muria selaras dengan pendapat Lickon yang menyatakan cinta damai merupakan perasaan kuat

\footnotetext{
${ }^{25}$ Toni Nasution, "Membangun Kemandirian Siswa Melalui Pendidikan Karakter," Ijtimaiyah, Vol. 2, No. 1.

26 Thomas Lickona, Pendidikan Karakter: Panduan Lengkap Mendidik Siswa Menjadi Pintar dan Baik....

${ }^{27}$ Dharma Kesuma, Pendidikan Karakter: Kajian Teori dan Praktik di Sekolah....
} 
untuk berbuat baik yang memberikan rasa tenang, aman, dan bahagia kepada orang lain. ${ }^{28}$

\section{Nilai Peduli Sosial}

Pada cerita rakyat Sunan Muria terdapat nilai peduli sosial antara lain yang dilakukan oleh Sunan Muria yang peduli terhadap Umara dan Umari yang berubah menjadi bulus. Hal ini sesuai dengan pernyataan Kesuma yang menyatakan nilai peduli sosial merupakan sikap tanggap, peduli, dan berbagi dalam kehidupan masyarakat. ${ }^{29}$

\section{Nilai Tanggung Jawab}

Pada cerita rakyat Sunan Muria terdapat nilai tanggungjawab antara lain yang dilakukan oleh Mbah Onggowongso ketika diberi kepercayaan oleh Sunan Muria untuk merawat kudanya, Mbah Onggowongso bertanggungjawab sepenuhnya atas tugas yang diberikan oleh gurunya.

Cerita Rakyat Sunan Muria di Kabupaten Kudus merupakan bentuk kearifan lokal yang dapat digunakan sebagai salah satu materi cerita rakyat dalam mata pelajaran Bahasa Jawa. Cerita Rakyat Sunan Muria memuat pesan-pesan moral yang dapat menjadi perantara untuk menanamkan pendidikan karakter kepada siswa. Siswa diharapkan meneladani tokoh-tokoh dalam Cerita Rakyat Sunan Muria dan menerapkan pendidikan karakter dalam kehidupan sehari-hari. Hal ini menunjukkan bahwa nilai-nilai pendidikan karakter yang terkandung dalam Cerita Rakyat Sunan Muria memiliki relevansi dengan pembelajaran bahasa Jawa yang menekankan pembentukan budi pekerti kepada siswa. Temuan nilai tanggungjawab di dalam cerita rakyat Sunan Muria selaras dengan pendapat Kesuma yang menyatakan nilai tanggungjawab mencerminkan sikap seseorang untuk menanggung dan mengemban tugas dan kewajiban dengan baik. ${ }^{30}$

\section{Penutup}

Struktur yang membangun Cerita Rakyat Sunan Muria di Kabupaten Kudus meliputi: (1) tema tentang pengabdian seorang murid kepada guru dan

\footnotetext{
${ }^{28}$ Thomas Lickona, Pendidikan Karakter: Panduan Lengkap Mendidik Siswa Menjadi Pintar dan Baik....

${ }^{29}$ Dharma Kesuma, Pendidikan Karakter: Kajian Teori dan Praktik di Sekolah....

${ }^{30}$ Dharma Kesuma, Pendidikan Karakter: Kajian Teori dan Praktik di Sekolah....
} 
tentang percintaan; (2) alur yang digunakan pada kelima cerita rakyat Sunan Muria adalah alur maju; (3) tokoh yang terlibat pada Cerita Rakyat Sunan Muria didominasi oleh tokoh berkarakter baik; (4) latar atau setting yang digunakan pada cerita rakyat Sunan Muria didominasi oleh latar tempat; dan (5) amanat yang terkandung dalam Cerita Rakyat Sunan Muria antara lain: (a) sebagai seorang murid sebaiknya mematuhi dan menjalankan perintah guru dengan baik dan penuh tanggungjawab; (b) sebagai seorang guru dan orang tua sebaiknya tidak memaksa menjodohkan anak dengan orang yang bukan merupakan pilihan hatinya. Orang tua juga harus menerapkan sikap demokratis dengan mamahami dan menghargai pendapat anak.

Nilai pendidikan karakter dalam Cerita Rakyat Sunan Muria di Kabupaten Kudus meliputi: (1) nilai religius, (2) nilai kejujuran, (3) nilai toleransi, (4) nilai disiplin, (5) nilai kerja keras, (6) nilai mandiri, (7) nilai demokratis, (8) nilai bersahabat/ komunikatif, (9) nilai cinta damai, (10) nilai peduli sosial, dan (11) nilai tanggungjawab. Kesebelas nilai pendidikan karakter tersebut memiliki kontribusi dalam pembelajaran materi cerita rakyat di sekolah dengan menyesuaikan jenjang pendidikannya.

\section{Daftar Pustaka}

Ananda, Refisa. 2015. Kajian Fungsi Sastra Lisan Kaba Urang Tanjuang Karang Pada Pertunjukan Dendang Pauah. STKIP Siliwangi Journals, 4(2): 92122.

Bahtiar, Ahmad Bahtiar. "Sikap Pengarang dalam Novel Palawidja Karya Karim Halim dan Kembang Jepung Karya Remi Silado: Sebuah Bandingan.” Jurnal Adabiyat: Jurnal Bahasa dan Sastra. Vol. 4, No. 1.

Duffin, Christopher J. "A Survey of Birds and Fabulous Stones." Journal of Folklore Research. Vol. 123, No. 2.

Dwi, Trinil Turistiani. "Struktur Alur Dan Bentuk Konflik Yang Membangun Novel Saman Karya Ayu Utami.” Jurnal Pena Indonesia. Vol. 3, No. 2.

Fatmawati, Laila, dkk. "Buku Cerita Edukatif Berbasis Karakter Toleransi Sebagai Inovasi Mengenalkan Pendidikan Multikultural.” Jurnal Penelitian Pendidikan. Vol. 35, No. 2.

Gencarella, Stephen Olbrys. "Gramsci, Good Sense, and Critical Folklore Studies." Journal of Folklore Research, Vol. 47, No. 3.

Gunnell, Terry. "Daisies Rise to Become Oaks. The Politics of Early Folktale Collection in Northern Europe." Journal of Folklore Research. Vol. 121, No. 1. 
Gusnetti, Syofiani dan Romi Isnanda. "Struktur dan Nilai-nilai Pendidikan dalam Cerita Rakyat Kabupaten Tanah Datar Provinsi Sumatera Barat." Jurnal Gramatika. Vol. 1, No. 2.

Haryanti, Novi Diah. "Bidadari dan Si Penggoda Representasi Tokoh-Tokoh Perempuan dalam Novel Student Hidjo.” Jurnal Dialektika. Vol. 4, No. 1 .

Kesuma, Dharma. Pendidikan Karakter: Kajian Teori dan Praktik di Sekolah. Bandung: PT. Remaja Rosdakarya, 2012.

Lickona, Thomas. Pendidikan Karakter: Panduan Lengkap Mendidik Siswa Menjadi Pintar dan Baik. Bandung: Nusa Media, 2013.

Messi dan Edi Harapan. "Menanamkan Nilai Nilai Kejujuran di Dalam Kegiatan Madrasah Berasrama (Boarding School).” Jurnal Manajemen, Kepempimpinan, dan Supervisi Pendidikan, Vol. 1, No. 1.

Mieder, Wolfgang. "Now I Sit Lake a Rabbit in the Pepper." Journal of Folklore Research, Vol. 40, No. 1.

Muslich, Masnur. Pendidikan Karakter: Menjawab Tantangan Krisis Multidimensional. Jakarta: Bumi Aksara, 2011.

Nasution, Toni. "Membangun Kemandirian Siswa Melalui Pendidikan Karakter." Ijtimaiyah. Vol. 2, No. 1.

Nurgiantoro, Burhan. Dasar Dasar Kajian Fiksi. Yogyakarta: Usaha Mahasiswa, 2005.

Purwandi, Eko, Emi Agustina \& Amril Canhras. 2018. Nilai Religius Dan Nilai Sosial Dalam Materi Pembelajaran Sastra (Cerpen) Pada Buku Teks Bahasa Indonesia SMP/MTS Kelas VIII. Jurnal Ilmiah KORPUS, 2(2): 154-159.

Putri, Nazella S dan Ali Mustofa. "Nilai Religius dalam Novel Assalamulaikum Beijing Karya Asma Nadia dan Implikasinya." Jurnal Kata: (Bahasa, Sastra dan Pembelajarannya). Vol. 6, No. 1.

Schwatz, Amy Gazin. Archaeology and Folklore of Material Culture, Ritual, and Everyday Life International. Journal of Historical Archaeology. Vol. 5, No. 4.

Sulastri, Saptiana dan Al Ashadi Alimin. Nilai Pendidikan Karakter Kerja Keras Dalam Novel 2 Karya Donny Dhirgantoro. Jurnal Pendidikan Bahasa. Vol. 6, No. 2.

Usman, Muhammad dan Anton Widyanto. Internalisasi Nilai-Nilai Toleransi dalam Pembelajaran Pendidikan Agama Islam di SMA Negeri 1 Lhokseumawe, Aceh, Indonesia. Dayah: Journal of Islamic Education. Vol. 2, No. 1.

Waluyo, Herman J. Apresiasi Prosa dan Drama. Surakarta: UNS Press, 2002. 